\section{Naming names}

John M. Charap

Moscow and Beyond. By Andrei

Sakharov. Knopf: 1991. Pp.168. £14.99, \$19.95.

IN December 1986 Andrei Sakharov received a telephone call from Mikhael Gorbachev, recalling him to Moscow from his seven-year exile in Gorky to "resume his patriotic work". His Memoirs (published last year by Hutchinson), end with that call. By the early 1970 s his was the clearest voice from within the Soviet Union, speaking with conviction, reason and passion for civil rights, for an end to the nuclear confrontation with the West, for an end to the rape of the environment in the Soviet Union. His opposition to the war in Afghanistan brought him exile by Brezhnev. Just three years after his recall to Moscow, Sakharov was dead. Moscow and Beyond is his account of those three years.

Back in Moscow in their small apartment, Sakharov and his wife Lusia (Yelena Bonner) received a stream of ambassadors, wellwishers and journalists. Lusia cooked for them, then took her turn to mop the landing of their communal building before typing his letters and press statements. Perhaps Gorbachev expected that these two ailing, elderly campaigners would leave it at that. But Sakharov took every opportunity to campaign against the continued detention of prisoners of conscience, stressing the inconsistency with the dynamic of perestroika. And he would name names, for it was always necessary to reinforce the general argument with particular individual cases.

Within weeks, Evgeny Velikhov invited him to take part in a Forum for a NuclearFree World to be held in Moscow in February 1987 . Sakharov used that forum to elaborate his views on convergence - the rapprochement of the socialist and capitalist systems - and the nuclear disarmament which must go with it. Specifically, he criticized with reason and vigour the prevailing policy of the Soviet Union which linked negotiations on arms limitation to abandonment by the United States of the Strategic Defense Initiative (Star Wars); within two weeks the Soviet Union renounced this package principle with respect to intermediate range missiles (and later with respect to shorter-range and intercontinental ballistic missiles too).

During the Forum and in the following months, Sakharov met many western scientists, some old friends, others for the first time. But there is only scant reference to the substance of his scientific interests, and what there is betrays a nostalgia for when he was himself active in research. We learn little directly about his personal life, except for the deep love and companionship which Lusia brought to it. He was closer to her children than to his own from his first marriage, and his elliptic, diffident mention of them is painful to read (as it probably was to write). Sakharov was more at ease writing about his public life which now became a whirlwind of activity.

Those last three years were crucial and testing years for perestroika. Sakharov was now a major participant, directly involved in the events which shook the country. Already in 1987 (unlike many in the West) he was not bedazzled in his appraisal of Gorbachev whom he saw as "trying to gain control of the political situation and strengthen his personal power by compromising with the forces opposed to perestroika instead of relying on democratic reforms. That's extremely dangerous."

Visiting Estonia in 1987, he recognized the example set by the Baltic Republics "with their popular movements for a genuine, not a fictitious perestroika and for a radical resolution of nationality problems through economic autonomy and the adoption of a new compact between the Union and its constituent Republics." Within weeks of the explosive eruption of interethnic violence in Nagorno-Karabakh in 1988 Sakharov had written an open letter to Gorbachev, and the fumbling efforts of the Kremlin to reconcile the Armenians and the Azerbaijanis was one of the first issues addressed by the Moscow Tribune, "a club, in effect an embryonic legal opposition" he had helped to found. Then on 7 December Armenia was shaken by an earthquake: Gorbachev flew back from the United States to visit the disaster area, only to be harangued by grieving people. On his way back to Moscow from his first trip abroad (he had met with Reagan, Bush, Shultz - and Thatcher - in New York, and was now a guest of President Mitterand in Paris), Sakharov immediately appealed for foreign assistance for the earthquake victims. He also discussed Nagorno-Karabakh with Mitterand, and $a ̀$ propos the fate of the Iraqi Kurds received an assurance that France would cut off military assistance to Iraq. Within days he was asked by Alexander Yakovlev, a Senior Secretary of the Central Committee and radical reformer among the party elite, to go to Armenia and Azerbaijan. He was appalled by what he found there, the corruption and ineptitude which frustrated the distribution of relief supplies, the plight of the refugees from both sides of the conflict, the stories of violence and torture. What the Moscow authorities were doing was too little and too late. Sadly, his advice seems to have made little impression on the authorities.

The book ends with the 1989 Congress of
People's Deputies, that extraordinary fortnight of turbulent debate under the eyes of the television cameras, the nation and the world. Sakharov had been elected (not without a struggle) as a representative from the Academy of Sciences, and from the start played a prominent and influential role. For him the central issue was constitutional reform. In the closing minutes of the Congress he proposed a Decree on Power (starting with repeal of Article 6 of the Soviet constitution, which ordained the Communist Party's monopoly of power - a proposal finally adopted in March 1990); proposed dramatic cuts in the armed forces; proposed "the creation of a new constitution based on horizontal federalism" which would give effective independence within the Union to the Republics; addressed the problem of the forcibly resettled nationalities (Crimean Tatars, for example); and stressed that "the most urgent political question is the confir- 